\title{
Picotamide reduced all cause mortality more than aspirin in type 2 diabetes mellitus and peripheral arterial disease
}

Neri Serneri GG, Coccheri S, Marubini E, et al. Picotamide, a combined inhibitor of thromboxane A2 synthase and receptor, reduces 2-year mortality in diabetics with peripheral arterial disease: the DAVID study. Eur Heart J 2004;25:1845-52.

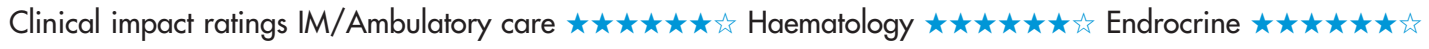

In patients with type 2 diabetes mellitus and peripheral arterial disease (PAD), is picotamide better than aspirin for preventing all cause mortality and major cardiovascular (CV) events?

\section{METHODS}

\begin{tabular}{|c|c|}
\hline \multirow{3}{*}{$\square$} & $\begin{array}{l}\text { Design: randomised placebo controlled trial (Drug Evaluation in } \\
\text { Atherosclerotic Vascular Disease in Diabetics [DAVID] study). }\end{array}$ \\
\hline & Allocation: concealed.* \\
\hline & $\begin{array}{l}\text { Blinding: blinded (clinicians, patients, data collectors, outcome } \\
\text { assessors, and data safety and monitoring committee). }{ }^{*}\end{array}$ \\
\hline \multirow{2}{*}{$\sum$} & Follow up period: 24 months. \\
\hline & Setting: 86 centres in Italy. \\
\hline (2) & $\begin{array}{l}\text { Patients: } 1209 \text { patients who were } 40-75 \text { years of age (mean } \\
\text { age } 64 \mathrm{y}, 73 \% \text { men) with type } 2 \text { diabetes for } \geqslant 5 \text { years and PAD } \\
\text { ( } \geqslant 2 \text { of intermittent claudication for }>2 \mathrm{mo} \text {, loss of posterior tibial } \\
\text { pulse in the foot, ankle/arm pressure ratio }<0.90 \text { or }>1.30 \text { in } \\
\text { the posterior or anterior tibial artery of the foot, amputation or } \\
\text { reconstructive surgery in patients with previous intermittent } \\
\text { claudication, or angioplasty). Exclusion criteria included } \\
\text { myocardial infarction (MI), stroke, or unstable angina in the } \\
\text { previous } 6 \text { months; severe neurological or mental deficits; severe } \\
\text { comorbid conditions that would limit life expectancy to }<2 \text { years; } \\
\text { serum creatinine }>2.0 \mathrm{mg} / \mathrm{dl}(176 \mu \mathrm{mol} / \mathrm{l}) \text {; pregnancy; severe } \\
\text { uncontrolled hypertension; active peptic ulcer or gastroenteric } \\
\text { bleeding in the previous } 6 \text { months; total cholesterol concentration } \\
\geqslant 300 \mathrm{mg} / \mathrm{dl}(7.69 \mathrm{mmol} / \mathrm{ll} \text { ); and need for long term use of } \\
\text { anticoagulants. }\end{array}$ \\
\hline & $\begin{array}{l}\text { Intervention: patients were stratified by centre and allocated to } \\
\text { twice daily picotamide, } 600 \mathrm{mg}(\mathrm{n}=603) \text {, or aspirin, } 320 \mathrm{mg} \text { in } \\
\text { the morning and a placebo tablet in the evening }(n=606) \text {. }\end{array}$ \\
\hline 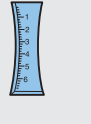 & $\begin{array}{l}\text { Outcomes: all cause mortality. Secondary outcomes were the } \\
\text { composite endpoint of death and non-fatal CV events (MI, } \\
\text { ischaemic stroke, or major amputation [above the ankle, not } \\
\text { because of trauma or cancer]), and adverse events. }\end{array}$ \\
\hline \multirow[t]{2}{*}{$\vec{\square}$} & Patient follow up: $95 \%$ (intention to treat analysis). \\
\hline & ${ }^{*}$ See glossary. \\
\hline
\end{tabular}

\section{MAIN RESULTS}

Picotamide led to fewer deaths than did aspirin (table). The groups did not differ for the composite endpoint of mortality plus non-fatal $\mathrm{CV}$ events (table). Picotamide was associated with fewer gastrointestinal adverse events than aspirin $(11 \% \vee 18 \%, \mathrm{p}<0.001)$. The groups did not differ for other adverse events.

For correspondence: Dr S Coccheri, University of Bologna, Bologna, Italy. coccheri@med.unibo.it

Source of funding: Novartis S.p.a.

\section{CONCLUSIONS}

In patients with type 2 diabetes mellitus and peripheral arterial disease, picotamide reduced death more than did aspirin. Picotamide did not reduce non-fatal cardiovascular events.

Abstract and commentary also appear in ACP Journal Club.

Picotamide $v$ aspirin for type 2 diabetes mellitus and peripheral arterial disease*

\begin{tabular}{lllll}
$\begin{array}{l}\text { Outcomes at } \\
\mathbf{2 4} \text { months }\end{array}$ & Picotamide & Aspirin & RRR (95\% CI) & NNT (CI) \\
\hline $\begin{array}{l}\text { All cause } \\
\text { mortality }\end{array}$ & $2.8 \%$ & $5.1 \%$ & $45 \%(2$ to 69) & 44 (22 to 1025) \\
$\begin{array}{l}\text { Composite } \\
\text { endpoint }\end{array}$ & $7.5 \%$ & $9.0 \%$ & $16 \%(-22$ to 43$)$ & Not significant \\
& & & &
\end{tabular}

${ }^{*}$ Composite endpoint $=$ death and non-fatal cardiovascular events. Other abbreviations defined in glossary; RRR, NNT, and Cl calculated from data in article.

\section{Commentary}

P atients with type 2 diabetes have increased platelet adhesiveness. ' As a result, aggressive antiplatelet therapy would be expected to improve CV outcomes. However, 2 recent publications have shown that while aspirin improved CV outcomes in non-diabetic patients, this was not the case in patients with diabetes. ${ }^{2}{ }^{3}$

Aspirin inhibits platelet cyclooxygenase activity, leading to a decrease in thromboxane A2 (a potent platelet activator) while simultaneously decreasing the production of prostacyclin (a mediator known to decrease platelet aggregation and to produce vasodilation). The reduced benefit of aspirin in patients with diabetes is thought to occur because the loss of thromboxane $\mathrm{A} 2$ is minimised by the presence of numerous other platelet activators/aggregators present in the diabetic state. Thus, the platelet remains activated/aggregable while having lost the antiaggregating influence of prostacyclin. As a result, specific thromboxane A2 blockers have been developed to provide antithromboxane benefits without lowering prostacyclin concentrations.

The 24 month DAVID study by Serneri et al compared picotamide with daily aspirin in patients with type 2 diabetes and PAD, and showed a decreased risk of all cause mortality. The only disappointing finding was the non-significant reduction of the composite endpoint of mortality and non-fatal CV events. This leaves the interpretation difficult and a need for further confirmatory trials.

If proven equivalent to or better than aspirin in $\mathrm{CV}$ prevention, picotamide (which causes less bleeding requiring hospital admission and a lower frequency of gastrointestinal discomfort than aspirin) will be a welcome addition to calm the hyperactive platelets in diabetic patients. As we wait, the current recommendation by the American Diabetes Association of the use of daily aspirin (75-162 mg) in diabetic patients with vascular disease, age $>40$ years, or with additional $\mathrm{CV}$ risk factors, should be followed. ${ }^{4}$ Donald A Smith, MD, MPH Mount Sinai School of Medicine, New York, New York, USA 1 Colwell JA, Nesto RW. Diabetes Care 2003;26:2181-8.

2 Antithrombotic Trialists' Collaboration. BMJ 2002;324:71-86.

3 Sacco M, Pellegrini F, Roncaglioni MC, et al. Diabetes Care 2003:26:3264-72

4 Colwell JA. Diabetes Care 2004;27(Suppl 1):S72-3. 